Article

\title{
Incidental Use of Beta-Blockers Is Associated with Outcome of Metastatic Colorectal Cancer Patients Treated with Bevacizumab-Based Therapy: A Single-Institution Retrospective Analysis of 514 Patients
}

\author{
Ondrej Fiala ${ }^{1,2}, * \mathbb{D}$, Pavel Ostasov ${ }^{2}$, Ondrej Sorejs ${ }^{1,2}$, Vaclav Liska ${ }^{2,3}$, Tomas Buchler ${ }^{4}$, \\ Alexandr Poprach ${ }^{5}$ and Jindrich Finek ${ }^{1}$ \\ 1 Department of Oncology and Radiotherapy, Medical School and University Hospital in Pilsen, Charles \\ University, alej Svobody 80, 30460 Pilsen, Czech Republic; sorejso@fnplzen.cz (O.S.); finek@fnplzen.cz (J.F.) \\ 2 Biomedical Center, Faculty of Medicine in Pilsen, Charles University, alej Svobody 76, \\ 32300 Pilsen, Czech Republic; pavel.ostasov@lfp.cuni.cz (P.O.); liskav@fnplzen.cz (V.L.) \\ 3 Department of Surgery, Medical School and University Hospital in Pilsen, Charles University, alej Svobody \\ 80, 30460 Pilsen, Czech Republic \\ 4 Department of Oncology, First Faculty of Medicine, Charles University and Thomayer Hospital, Videnska \\ 800, 14059 Prague, Czech Republic; tomas.buchler@ftn.cz \\ 5 Department of Comprehensive Cancer Care and Faculty of Medicine, Masaryk Memorial Cancer Institute \\ and Masaryk University, Zluty kopec 7, 65653 Brno, Czech Republic; poprach@mou.cz \\ * Correspondence: fialao@fnplzen.cz; Tel.: +42-0728-655-488
}

Received: 13 October 2019; Accepted: 19 November 2019; Published: 25 November 2019

\begin{abstract}
Background: Beta-adrenergic signalling plays an important role in several cancer-related processes, including angiogenesis. The impact of beta-blocker use on prognosis of cancer patients treated with antiangiogenic agents is unclear. The aim of this study was to evaluate the association between the incidental use of beta-blockers and the outcomes of patients with metastatic colorectal cancer (mCRC) treated with bevacizumab-based therapy. Methods: Clinical data from 514 mCRC patients treated with bevacizumab between 2005 and 2019 were analysed retrospectively. The association of progression-free survival (PFS) and overall survival (OS) with the incidental use of beta-blockers and other common antihypertensive drugs was assessed. Results: The median PFS and OS for patients using beta-blockers was 11.40 (95\% confidence interval (CI) 10.10-13.61) months and 26.8 (95\% CI 22.2-32.2) months compared with 8.30 (95\% CI 7.80-9.57) and 21.0 (95\% CI 17.8-23.8) months for patients not using beta-blockers ( $p=0.006$ and $p=0.009$, respectively). In the Cox multivariate analysis, the use of beta-blockers was a significant factor predicting both PFS (hazard ratio $(\mathrm{HR})=0.763$ (95\% CI 0.606-0.960), $p=0.021$ ) and OS (HR $=0.730$ (95\% CI 0.560-0.951), $p=0.020)$. Conclusions: The results of the present retrospective study suggest that there is a significant association between the use of beta-blockers and favourable outcomes of $\mathrm{mCRC}$ patients treated with bevacizumab-based therapy.
\end{abstract}

Keywords: colorectal cancer; bevacizumab; beta-blocker; outcome; hypertension

\section{Background}

Colorectal cancer (CRC) is one of the most common malignancies in developed countries [1]. Bevacizumab represents one of the established targeted agents for the treatment of metastatic CRC (mCRC). A recombinant humanised monoclonal antibody directed against vascular endothelial growth 
factor A (VEGF-A), it is commonly used in combination with standard chemotherapy regimens consisting of 5-fluorouracil and oxaliplatin and/or irinotecan. The efficacy and safety of bevacizumab in the treatment of patients with $\mathrm{mCRC}$ have been demonstrated in randomised phase III clinical trials as well as observational studies [2-6].

Beta-adrenergic receptor antagonists (beta-blockers) have been widely used for the treatment of arterial hypertension and ischaemic heart disease for decades. There is a growing body of evidence that beta-adrenergic receptor downstream signalling plays an important role in several cancer-related processes, such as cell proliferation, apoptosis, invasion and angiogenesis [7]. Experimental studies have suggested the antitumour activity of beta-blockers, but the impact of beta-blocker use on outcomes in cancer patients is still poorly understood [8-14]. Although several retrospective studies have shown that the use of beta-blockers is associated with better prognosis of patients with various cancers, there are only limited data on the role of beta-blockers in patients with mCRC, particularly in those treated with targeted agents. The aim of this study was to evaluate the association between the incidental use of beta-blockers and the outcomes of patients with metastatic colorectal cancer treated with a combination of bevacizumab and chemotherapy.

\section{Materials and Methods}

\subsection{Study Design}

Clinical data of patients with mCRC treated with a combination of bevacizumab and chemotherapy were analysed retrospectively. The association of progression-free survival (PFS) and overall survival (OS) with the incidental use of beta-blockers as well as other commonly used antihypertensive drugs, including angiotensin-converting-enzyme inhibitors (ACE inhibitors), angiotensin II receptor blockers (sartans) and calcium channel blockers, was assessed. The data on clinical characteristics, including the use of antihypertensive drugs and the follow-up, were obtained from medical records.

\subsection{Patients and Treatment}

In total, 514 adult patients with histologically confirmed mCRC treated with bevacizumab-based therapy between 2005 and 2019 at the Department of Oncology and Radiotherapy, Medical School and University Hospital Pilsen, Czech Republic were included in the study. Baseline characteristics of the patient group are described in Table 1 .

Bevacizumab (Avastin, F. Hoffman-La Roche Ltd., Basel, Switzerland) was administered in standard approved doses $(5.0 \mathrm{mg} / \mathrm{kg}$ every $14 \mathrm{~d}$ or $7.5 \mathrm{mg} / \mathrm{kg}$ every $21 \mathrm{~d}$ ) in combination with chemotherapy or as a single agent in the maintenance setting. The chemotherapy regimens included 5-fluorouracil and leucovorin in combination with oxaliplatin (FOLFOX) or irinotecan (FOLFIRI), or 5-fluorouracil and leucovorin (FUFA); capecitabine in combination with oxaliplatin (XELOX) or irinotecan (XELIRI), or capecitabine alone; oxaliplatin alone; and irinotecan alone. None of the patients had received prior antiangiogenic therapy. The status of the antihypertensive therapy was assessed at the start of the treatment with bevacizumab-based therapy and all the antihypertensive drugs were administered orally at individual doses. Bevacizumab was administered in patients with compensated arterial hypertension.

The protocol of the study and the informed consent form for participants were approved by the Ethical Committee of the Medical School and University Hospital in Pilsen on 13 June 2016 and complied with the International Ethical Guidelines for Biomedical Research, the Declaration of Helsinki and local laws. Informed consent with subsequent analysis of the follow-up data was obtained from all the participants. 
Table 1. Baseline patient characteristics.

\begin{tabular}{|c|c|c|c|c|}
\hline \multirow{2}{*}{ Characteristic } & \multirow{2}{*}{ Category } & \multicolumn{2}{|c|}{ Use of Beta-Blockers } & \multirow{2}{*}{ Overall } \\
\hline & & No & Yes & \\
\hline \multicolumn{5}{|l|}{ Gender } \\
\hline & Male & $248(63.9 \%)$ & $90(71.4 \%)$ & $338(65.8 \%)$ \\
\hline & Female & $140(36.1 \%)$ & $36(28.6 \%)$ & $176(34.2 \%)$ \\
\hline \multicolumn{5}{|l|}{ Age } \\
\hline & Median (range) & $62.3(28.0,86.1)$ & $65.8(39.9,82.6)$ & $63.2(28.0,86.1)$ \\
\hline & $<70$ years & $309(79.6 \%)$ & $98(77.8 \%)$ & $407(79.2 \%)$ \\
\hline & $\geq 70$ years & $79(20.4 \%)$ & $28(22.2 \%)$ & $107(20.8 \%)$ \\
\hline \multicolumn{5}{|l|}{ ECOG PS } \\
\hline & 0 & $39(10.1 \%)$ & $9(7.1 \%)$ & $48(9.3 \%)$ \\
\hline & 1 & $346(89.2 \%)$ & $116(92.1 \%)$ & $462(89.9 \%)$ \\
\hline & 2 & $3(0.8 \%)$ & $1(0.8 \%)$ & $4(0.8 \%)$ \\
\hline \multicolumn{5}{|c|}{ Primary tumour location } \\
\hline & Left & $285(73.5 \%)$ & $90(71.4 \%)$ & $375(73.0 \%)$ \\
\hline & Right & $88(22.7 \%)$ & $32(25.4 \%)$ & $120(23.3 \%)$ \\
\hline & Transversum & $15(3.9 \%)$ & $4(3.2 \%)$ & $19(3.7 \%)$ \\
\hline \multicolumn{5}{|l|}{ Line of therapy } \\
\hline & First line & $329(84.8 \%)$ & $114(90.5 \%)$ & $443(86.2 \%)$ \\
\hline & Second line & $56(14.4 \%)$ & $12(9.5 \%)$ & $68(13.2 \%)$ \\
\hline & Third line & $3(0.8 \%)$ & $0(0 \%)$ & $3(0.6 \%)$ \\
\hline \multicolumn{5}{|l|}{ Chemotherapy } \\
\hline & FOLFIRI or XELIRI & $72(18.6 \%)$ & $19(15.1 \%)$ & $91(17.7 \%)$ \\
\hline & FOLFOX or XELOX & $206(53.1 \%)$ & $74(58.7 \%)$ & $280(54.5 \%)$ \\
\hline & Other & $69(17.8 \%)$ & $24(19.0 \%)$ & $93(18.1 \%)$ \\
\hline & Data not available & $41(10.6 \%)$ & $9(7.1 \%)$ & $50(9.7 \%)$ \\
\hline \multicolumn{5}{|c|}{ Lines of subsequent chemotherapy } \\
\hline & No & $228(58.8 \%)$ & $69(54.8 \%)$ & $297(57.8 \%)$ \\
\hline & One & $102(26.3 \%)$ & $35(27.8 \%)$ & $137(26.7 \%)$ \\
\hline & Two & $39(10.1 \%)$ & $17(13.5 \%)$ & $56(10.9 \%)$ \\
\hline & Three & $16(4.1 \%)$ & $5(4.0 \%)$ & $21(4.1 \%)$ \\
\hline & Four & $3(0.8 \%)$ & $0(0 \%)$ & $3(0.6 \%)$ \\
\hline \multicolumn{5}{|c|}{$\begin{array}{l}\text { Lines of subsequent chemotherapy } \\
\text { combined with targeted therapy }\end{array}$} \\
\hline & No & $302(77.8 \%)$ & $100(79.4 \%)$ & $402(78.2 \%)$ \\
\hline & One & $85(21.9 \%)$ & $23(18.3 \%)$ & $108(21.0 \%)$ \\
\hline & Two & $1(0.3 \%)$ & $3(2.4 \%)$ & $4(0.8 \%)$ \\
\hline \multicolumn{5}{|c|}{$\begin{array}{c}\text { Lines of subsequent targeted } \\
\text { therapy }\end{array}$} \\
\hline & No & $291(75 \%)$ & $98(77.8 \%)$ & $389(75.7 \%)$ \\
\hline & One & $81(20.9 \%)$ & $26(20.6 \%)$ & $107(20.8 \%)$ \\
\hline & Two & $15(3.9 \%)$ & $1(0.8 \%)$ & $16(3.1 \%)$ \\
\hline & Three & $1(0.3 \%)$ & $1(0.8 \%)$ & $2(0.4 \%)$ \\
\hline
\end{tabular}


Table 1. Cont

\begin{tabular}{|c|c|c|c|c|}
\hline \multirow{2}{*}{ Characteristic } & \multirow{2}{*}{ Category } & \multicolumn{2}{|c|}{ Use of Beta-Blockers } & \multirow{2}{*}{ Overall } \\
\hline & & No & Yes & \\
\hline \multicolumn{5}{|c|}{ Synchronous metastases } \\
\hline & No & $160(41.2 \%)$ & $58(46.0 \%)$ & $218(42.4 \%)$ \\
\hline & Yes & $228(58.8 \%)$ & $68(54.0 \%)$ & $296(57.8 \%)$ \\
\hline \multicolumn{5}{|c|}{ Arterial hypertension } \\
\hline & No & $215(55.4 \%)$ & $99(78.6 \%)$ & $272(52.9 \%)$ \\
\hline & Yes & $173(44.6 \%)$ & $27(21.4 \%)$ & $242(47.1 \%)$ \\
\hline \multicolumn{5}{|c|}{ Ischaemic heart disease } \\
\hline & No & $369(95.1 \%)$ & $96(76.2 \%)$ & $465(90.5 \%)$ \\
\hline & Yes & $19(4.9 \%)$ & $30(23.8 \%)$ & $49(9.5 \%)$ \\
\hline \multicolumn{5}{|l|}{ Diabetes mellitus } \\
\hline & No & $327(84.3 \%)$ & $88(69.8 \%)$ & $415(80.7 \%)$ \\
\hline & Yes & $61(15.7 \%)$ & $38(30.2 \%)$ & $99(19.3 \%)$ \\
\hline \multicolumn{5}{|c|}{$\begin{array}{c}\text { Chronic obstructive pulmonary } \\
\text { disease }\end{array}$} \\
\hline & No & $383(98.7 \%)$ & $122(96.8 \%)$ & $505(98.2 \%)$ \\
\hline & Yes & $5(1.3 \%)$ & $4(3.2 \%)$ & $9(1.8 \%)$ \\
\hline \multicolumn{5}{|l|}{ Cancer duplicity } \\
\hline & No & $365(94.1 \%)$ & $104(82.5 \%)$ & $469(91.2 \%)$ \\
\hline & Yes & $23(5.9 \%)$ & $22(17.5 \%)$ & $45(8.8 \%)$ \\
\hline \multicolumn{5}{|c|}{ Chronic renal failure } \\
\hline & No & $381(98.2 \%)$ & $122(96.8 \%)$ & $503(97.9 \%)$ \\
\hline & Yes & $7(1.8 \%)$ & $4(3.2 \%)$ & $11(2.1 \%)$ \\
\hline \multicolumn{5}{|c|}{ Antihypertensive medication * } \\
\hline & Beta-blockers & $126(24.5 \%)$ & & \\
\hline & $\begin{array}{l}\text { Angiotensin-converting- } \\
\text { enzyme inhibitors }\end{array}$ & $163(31.7 \%)$ & & \\
\hline & $\begin{array}{l}\text { Angiotensin II receptor } \\
\text { blockers }\end{array}$ & 48 (9.3\%) & & \\
\hline & $\begin{array}{l}\text { Calcium channel } \\
\text { blockers }\end{array}$ & $102(19.8 \%)$ & & \\
\hline
\end{tabular}

* Patients with more antihypertensive medications were included in all relevant subgroups. ECOG PS: Eastern Cooperative Oncology Group performance status.

\subsection{Outcome Assessment}

The clinical status of the patients was assessed continuously during visits at prespecified time points. Physical examination and routine laboratory tests were performed every 2 weeks, and computed tomography (CT) was performed every 3-4 months during the treatment. The objective tumour response was assessed locally by the attending physician using Response Evaluation Criteria in Solid Tumors (RECIST) version 1.1 [15].

\subsection{Statistical Analysis}

Descriptive statistics and standard frequency tables were used to characterise the sample dataset. PFS was determined from the date of treatment initiation until the date of first documented progression or death. OS was determined from the date of treatment initiation until the date of death. In both cases, patients without event were censored at the date of last known follow-up. PFS and OS were estimated using the Kaplan-Meier method and all point estimates were accompanied by two-sided 
$95 \%$ confidence intervals. The statistical analysis was performed using $R$ (version 3.5.2) [16] with packages survival (version 2.43) [17] and survminer (version 0.4.3) [18] for survival analysis and visualisation. The log-rank test was used for assessment of statistical significance of the differences in survival according to treatment. A multivariate Cox proportional hazards model was used to evaluate the effect of all potential prognostic factors on the survival indicators and a univariate Cox model was used to determine the effect of individual antihypertension treatments on the survival indicators. The Wald test was used for assessment of statistical significance of hazard ratios. The level of statistical significance was set at $\alpha=0.05$ and all reported $p$-values are two-tailed.

\section{Results}

\subsection{Patient Characteristics}

The study included 514 patients. The baseline patient characteristics are summarised in Table 1. At the time of bevacizumab initiation, 126 (24.5\%) patients were using beta-blockers, $163(31.7 \%)$ were using ACE inhibitors, 48 (9.3\%) were using sartans and 102 (19.8\%) were using calcium channel blockers. Patients using more than one antihypertensive drug were not excluded. At the time of data analysis, $440(85.60 \%)$ patients progressed and $345(67.12 \%)$ patients died. The median follow-up time was $519 \mathrm{~d}$.

Median PFS and OS for the whole cohort were 9.18 months (95\% confidence interval (CI) 8.3-10.1) and 22.3 months (95\% CI 20.6-24.5), respectively.

\subsection{Outcome of Patients According to the Use of Beta-Blockers and Other Antihypertensive Drugs}

The univariate Cox analysis evaluating the impact of the use of various antihypertensive drugs on patients' survival revealed that only beta-blockers were significantly associated with PFS and OS (HR $=0.736$ (95\% CI 0.592-0.915), $p=0.006$ and HR $=0.714$ (95\% CI 0.554-0.921), $p=0.009$, respectively) (Table 2). The median PFS and OS for patients using beta-blockers were 11.40 months (95\% CI 10.10-13.61) and 26.8 months (95\% CI 22.2-32.2) compared with 8.30 months (95\% CI 7.80-9.57) and 21.0 months (95\% CI 17.8-23.8) for patients not using beta-blockers ( $p=0.006$ and $p=0.009$, respectively) (Table 3, Figure 1).

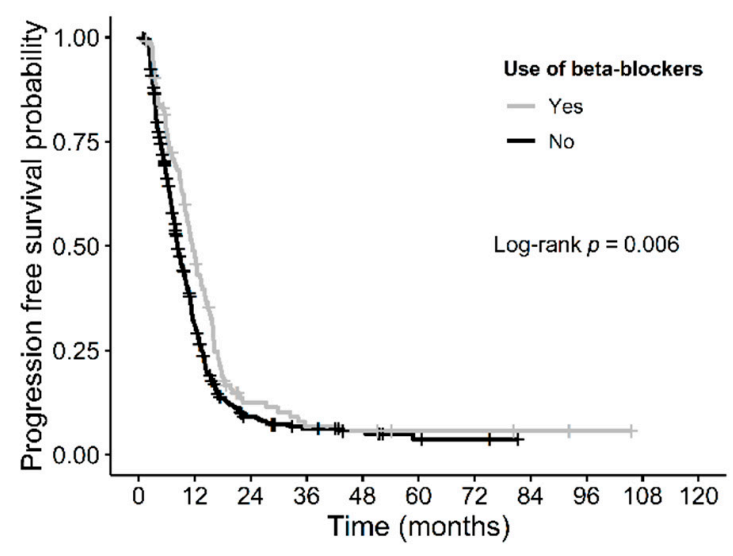

No. at risk

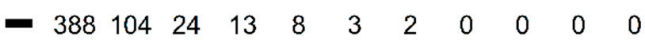

$\begin{array}{lllllllllll}126 & 56 & 11 & 6 & 5 & 3 & 3 & 2 & 1 & 0 & 0\end{array}$

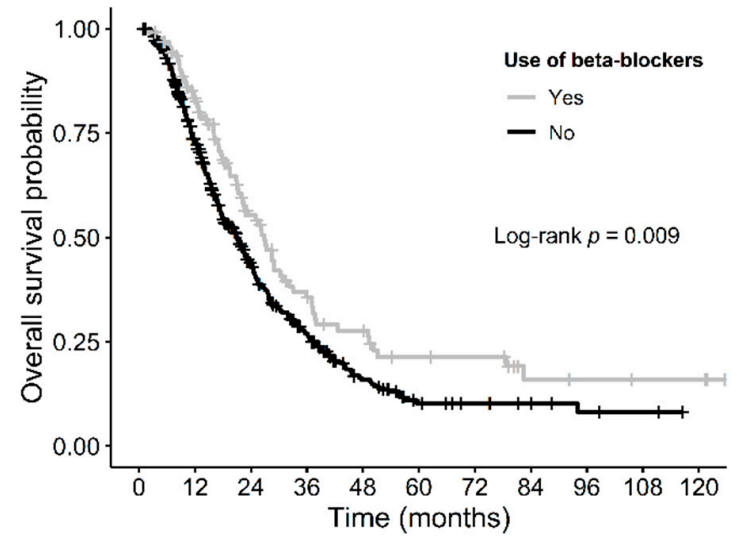

No. at risk

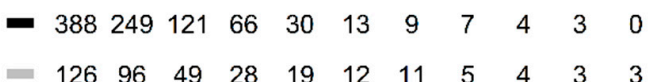

Figure 1. Kaplan-Meier estimates of progression-free survival (PFS) and overall survival (OS) according to the incidental use of beta-blockers. 
Table 2. Univariate Cox proportional hazards model assessing the impact of antihypertensive medication on progression-free survival and overall survival.

\begin{tabular}{ccccc}
\hline \multirow{2}{*}{$\begin{array}{c}\text { Medication } \\
\text { HR (95\% CI) }\end{array}$} & $\begin{array}{c}\text { Progression-Free Survival } \\
\mathbf{( P F S )}\end{array}$ & \multicolumn{2}{c}{ Overall Survival (OS) } \\
\cline { 2 - 5 } & Halue & HR (95\% CI) & $p$-Value \\
\hline $\begin{array}{c}\text { Angiotensin-converting-enzyme } \\
\text { inhibitors }\end{array}$ & $0.932(0.763-1.139)$ & 0.491 & $0.841(0.669-1.056)$ & 0.136 \\
\hline Beta-blockers & $0.736(0.592-0.915)$ & 0.006 & $0.714(0.554-0.921)$ & 0.009 \\
\hline Angiotensin II receptor blockers & $0.847(0.610-1.178)$ & 0.324 & $1.049(0.739-1.488)$ & 0.789 \\
\hline Calcium channel blockers & $0.886(0.700-1.121)$ & 0.313 & $0.932(0.716-1.214)$ & 0.603 \\
\hline
\end{tabular}

HR: hazard ratio; CI: confidence interval.

Table 3. Progression-free and overall survival according to the use of beta-blockers.

\begin{tabular}{cccc}
\hline \multirow{2}{*}{ Survival } & \multicolumn{2}{c}{ Use of Beta-Blockers } & \multirow{2}{*}{ No } \\
\cline { 2 - 3 } & Yes & \\
\hline Median PFS (95\% CI) & 8.30 months $(7.80-9.57)$ & 11.40 months & \\
3-month PFS (95\% CI) & $0.894(0.863-0.925)$ & $0.960(0.926-0.995)$ & 0.006 \\
6-month PFS (95\% CI) & $0.665(0.619-0.714)$ & $0.766(0.695-0.844)$ & \\
12-month PFS (95\% CI) & $0.309(0.264-0.361)$ & $0.472(0.392-0.571)$ & \\
18-month PFS (95\% CI) & $0.136(0.104-178)$ & $0.185(0.126-0.272)$ & \\
\hline Median OS (95\% CI) & 21.00 months $(17.8-23.8)$ & 26.8 months $(22.20-32.20)$ & \\
12-month OS (95\% CI) & $0.734(0.689-0.781)$ & $0.825(0.760-0.896)$ & 0.009 \\
24-month OS (95\% CI) & $0.439(0.388-0.497)$ & $0.553(0.465-0.656)$ & \\
36-month OS (95\% CI) & $0.269(0.223-0.326)$ & $0.357(0.271-0.471)$ & \\
\hline
\end{tabular}

In the Cox multivariate analysis, the use of beta-blockers was a significant factor predicting both PFS (HR $=0.763(95 \%$ CI 0.606-0.960), $p=0.021)$ and OS (HR = $0.730(95 \%$ CI 0.560-0.951), $p=0.020)$ (Table 4).

Table 4. Multivariate Cox proportional hazards model for progression-free and overall survival.

\begin{tabular}{|c|c|c|c|c|c|}
\hline \multirow[t]{2}{*}{ Parameter } & \multirow[t]{2}{*}{ Category } & \multicolumn{2}{|c|}{$\begin{array}{l}\text { Progression-Free Survival } \\
\text { (PFS) }\end{array}$} & \multicolumn{2}{|c|}{ Overall Survival (OS) } \\
\hline & & HR $(95 \%$ CI) & $p$-Value & HR (95\% CI) & $p$-Value \\
\hline \multirow[t]{2}{*}{ Gender } & Male & 1.000 & \multirow{2}{*}{0.985} & 1.000 & \multirow{2}{*}{0.302} \\
\hline & Female & $0.998(0.805-1.238)$ & & $1.133(0.894-1.437)$ & \\
\hline \multirow[t]{2}{*}{ Age } & $<70$ years & 1.000 & \multirow{2}{*}{0.459} & 1.000 & \multirow{2}{*}{0.813} \\
\hline & $\geq 70$ years & $1.100(0.855-1.414)$ & & $1.034(0.781-1.370)$ & \\
\hline \multirow[t]{3}{*}{ ECOG PS } & 0 & 1.000 & & 1.000 & \\
\hline & 1 & $1.066(0.776-1.464)$ & 0.693 & $1.136(0.782-1.650)$ & 0.503 \\
\hline & 2 & $0.614(0.183-2.058)$ & 0.430 & $0.828(0.244-2.810)$ & 0.763 \\
\hline \multirow[t]{2}{*}{$\begin{array}{l}\text { Primary tumour } \\
\text { location }\end{array}$} & Left & 1.000 & \multirow[t]{2}{*}{0.239} & 1.000 & \multirow[t]{2}{*}{0.361} \\
\hline & Right & $1.152(0.910-1.460)$ & & $1.131(0.868-1.476)$ & \\
\hline \multirow[t]{3}{*}{ Line of therapy } & First line & 1.000 & & 1.000 & \\
\hline & Second line & $1.127(0.816-1.557)$ & 0.468 & 1.011 (0.706-1.447) & 0.954 \\
\hline & Third line & $3.021(0.956-9.551)$ & 0.060 & $2.199(0.694-6.974)$ & 0.181 \\
\hline
\end{tabular}


Table 4. Cont.

\begin{tabular}{|c|c|c|c|c|c|}
\hline \multirow[t]{2}{*}{ Parameter } & \multirow[t]{2}{*}{ Category } & \multicolumn{2}{|c|}{$\begin{array}{c}\text { Progression-Free Survival } \\
\text { (PFS) }\end{array}$} & \multicolumn{2}{|c|}{ Overall Survival (OS) } \\
\hline & & HR $(95 \%$ CI) & $p$-Value & HR $(95 \%$ CI) & $p$-Value \\
\hline \multirow[t]{3}{*}{ Chemotherapy } & FOLFIRI or XELIRI & 1.000 & & 1.000 & \\
\hline & $\begin{array}{l}\text { FOLFOX or } \\
\text { XELOX }\end{array}$ & $0.782(0.693-1.013)$ & 0.062 & $0.656(0.496-0.870)$ & 0.003 \\
\hline & Other & $0.788(0.563-1.101)$ & 0.163 & $0.854(0.602-1.211)$ & 0.375 \\
\hline \multirow[t]{2}{*}{$\begin{array}{l}\text { Synchronous } \\
\text { metastases }\end{array}$} & No & 1.000 & 0.500 & 1.000 & 0.743 \\
\hline & Yes & $0.932(0.759-1.144)$ & & $0.963(0.768-1.207)$ & \\
\hline \multirow[t]{2}{*}{$\begin{array}{c}\text { Use of } \\
\text { beta-blockers }\end{array}$} & No & 1.000 & 0.021 & 1.000 & 0.020 \\
\hline & Yes & $0.763(0.606-0.960)$ & & $0.730(0.560-0.951)$ & \\
\hline
\end{tabular}

\section{Discussion}

The results of this retrospective, single-centre study suggest that the incidental use of beta-blockers is associated with superior PFS and OS in patients with mCRC treated with bevacizumab-based therapy. Apart from beta-blockers, there was no association between outcome of patients and incidental use of other commonly used antihypertensive drugs, including ACE inhibitors, sartans and calcium channel blockers. The multivariate Cox proportional hazards model confirmed that the incidental use of beta-blockers was an independent factor for PFS and OS.

Beta-adrenergic signalling mediates stress responses, also called "fight or flight", induced by the sympathetic nervous system via catecholamine neurotransmitters represented by adrenaline and noradrenaline. Beta-adrenergic receptors comprising three subtypes (beta- 1 , beta- 2 and beta-3) are constitutively expressed on most mammalian cells, including cancer cells [19]. Their activation can regulate a wide spectrum of cancer-related signalling pathways within both beta-adrenergic receptor expressing cancer cells and other beta-adrenergic receptor expressing cells present in the tumour microenvironment, such as vascular cells and macrophages [20]. The molecular background of several biological processes mediating beta-adrenergic influences on both cancer cells and the tumour microenvironment leading to tumour progression and metastatic spread have been identified. These cancer-related processes include promotion of cell proliferation [21,22], evasion of apoptosis [13,23], tissue invasion mediated by matrix metalloproteinases (MMP) [24], cancer cell mobilisation and motility [8,25], expression of proinflammatory cytokines such as interleukin 6 (IL-6) and IL-8 by both cancer and immune cells [26-28], recruitment of macrophages into the tumour [12] and angiogenesis $[24,29,30]$.

Multiple mechanisms contributing to tumour progression mediated by beta-adrenergic signalling suggest that beta-blockers may act as a promising auxiliary treatment strategy with pleiotropic effects on cancer cells and the tumour microenvironment. Various anticancer effects of beta-blocker treatment have been previously demonstrated in experimental models of CRC, pancreatic cancer, ovarian cancer, breast cancer and angiosarcoma [9-14]. However encouraging the results from experimental studies may be, the role of beta-blockers in cancer patients remains unclear and the results from mostly retrospective observational studies are equivocal. There are studies suggesting the use of beta-blockers may be able to prolong survival of cancer patients [31-49]. On the other hand, there are also studies that do not support such a hypothesis [50-60]. Similarly, the results from meta-analyses are ambiguous [61-63]. Regarding the role of beta-blocker use in patients with CRC, limited data have been obtained from several retrospective studies with inconclusive results. Moreover, scant data 
are available for patients with $\mathrm{mCRC}$, particularly those treated with targeted agents. Jansen et al. previously reported a stage-specific association between beta-blocker use and prognosis in patients with CRC in a large population-based retrospective study [42]. They did not find any significant effect of beta-blockers on OS, CRC-specific survival and recurrence-free survival in the whole patient population [42]. However, they did report a significantly longer OS (HR: 0.50, $p=0.0023$ ) and CRC-specific survival time (HR: $0.47, p=0.0017$ ) for the beta-blocker users in a subgroup of 256 patients with mCRC [42]. On the other hand, two other large retrospective studies did not find such an association $[59,60]$.

The role of beta-blockers in patients with $\mathrm{mCRC}$ treated with antiangiogenic targeted agents is unclear. It has been demonstrated that beta-adrenergic signalling can induce tumour angiogenesis by several distinct molecular mechanisms, including upregulation of VEGF expression in a hypoxia-inducible factor 1-alpha (HIF-1-alpha)-dependent manner and also expression of several other proangiogenic factors, such as IL-6, IL-8, MMP-2 and MMP-9 [24,26-30]. Beta-blockers have been shown to result in decreased VEGF expression and, thus, to an inhibition of angiogenesis $[24,64,65]$. The antiangiogenic effects of beta-blockers were clearly demonstrated on patients with infantile haemangiomas, in whom treatment with propranolol is commonly used with high efficacy $[66,67]$. These findings support the hypothesis that the use of beta-blockers could act synergistically with antiangiogenic targeted therapies and could improve the outcomes of cancer patients. To the best of our knowledge, until now, there has been only one retrospective study investigating the role of beta-blocker use in mCRC patients treated with bevacizumab [43]. The study, conducted by Giampieri et al., included $235 \mathrm{mCRC}$ patients treated with chemotherapy alone or with bevacizumab and showed significantly longer OS (HR: 2.26, $p=0.003)$ and a higher response rate $(p=0.044)$ for patients using beta-blockers in the subgroup treated with chemotherapy, while no significant differences were seen in the subgroup treated with bevacizumab [43]. The results of our study contrast with those reported by Giampieri et al. However, the limited number of patients included in their study should be pointed out, in particular those treated with bevacizumab. That study included only 107 patients treated with bevacizumab and only 9 of them used beta-blockers [43]. Thus, the results could be affected by heterogeneity and the small size of the cohort. The strengths of our study are the use of a relatively large cohort of patients and that the patients were diagnosed and treated with a similar strategy and under similar conditions at a single institution.

The present study has several limitations, including its retrospective design, the heterogeneity of the chemotherapy backbone regimens and the dosage and length of beta-blocker exposure not being assessed. Another limitation is that the addition of beta-blockers after initiation of bevacizumab-based therapy was not assessed. Therefore, the patients to whom a beta-blocker was given during the course of bevacizumab-based therapy were not included in the beta-blocker user cohort. This could affect the results because it has been reported that new manifestation or worsening of pre-existing arterial hypertension induced by bevacizumab is associated with a favourable outcome in mCRC patients [68]. On the other hand, the inclusion of these patients might introduce immortal time bias. Our study did not include a cohort treated with chemotherapy alone, and, therefore, it cannot be concluded with certainty that the use of beta-blockers augments the efficacy of bevacizumab or whether it could also improve prognosis of patients treated with chemotherapy alone or chemotherapy combined with other targeted agents. This question should be answered in prospective studies in the future. Nevertheless, this is the largest study published so far evaluating the association between incidental use of beta-blockers and outcome of mCRC patients treated with bevacizumab-based therapy.

\section{Conclusions}

The results of the present retrospective study suggest that there is a significant association between the use of beta-blockers and favourable outcome of mCRC patients treated with bevacizumab-based therapy. The efficacy and safety of the combination of beta-blockers with bevacizumab-based therapy should be investigated in a prospective controlled clinical trial in the future. Our study also indirectly 
indicates that beta-blockers might be a preferred type of antihypertensive drug for patients with mCRC, especially in those considered for treatment with bevacizumab.

Author Contributions: O.F. designed the study and wrote the manuscript with support from V.L., T.B., A.P. and J.F. O.S. collected clinical data. P.O. performed statistical analyses.

Funding: This study was supported by the project "Centre of Clinical and Experimental Liver Surgery", UNCE/MED/006; the National Sustainability Program I (NPU I) Nr. LO1503 provided by the Ministry of Education, Youth and Sports of the Czech Republic; the Charles University Research Fund (Progres Q39); and the European Regional Development Fund-Project "Application of Modern Technologies in Medicine and Industry" (No. CZ.02.1.01/0.0/0.0/17_048/0007280).

Acknowledgments: The authors would like to thank all patients voluntarily taking part in the study.

Conflicts of Interest: O.F. received honoraria from Roche, Janssen, Glaxo Smith Kline and Pfizer for consultations and lectures unrelated to this project. T.B. received lecture honoraria from Novartis, Pfizer, Bayer, Amgen, Servier, Bristol Myers Squibb, Astellas, Janssen and Roche, as well as research support from Roche, Servier and Novartis. A.P. received lecture honoraria from Novartis, Pfizer, Bayer-Schering and Roche. J.F. has received honoraria from Astra Zeneca, Roche and Novartis for consultations and lectures unrelated to this project. P.O., O.S. and V.L. declare that they have no actual or potential conflict of interest, including any financial, personal or other relationships with other people or organisations that could inappropriately influence this work.

\section{References}

1. Jemal, A.; Bray, F.; Center, M.M.; Ferlay, J.; Ward, E.; Forman, D. Global cancer statistics. CA Cancer J. Clin. 2011, 61, 69-90. [CrossRef]

2. Hurwitz, H.; Fehrenbacher, L.; Novotny, W.; Cartwright, T.; Hainsworth, J.; Heim, W.; Berlin, J.; Baron, A.; Griffing, S.; Holmgren, E.; et al. Bevacizumab plus irinotecan, fluorouracil and leucovorin for metastatic colorectal cancer. N. Engl. J. Med. 2004, 250, 2335-2342. [CrossRef] [PubMed]

3. Kabbinavar, F.F.; Hambleton, J.; Mass, R.D.; Hurwitz, H.I.; Bergsland, E.; Sarkar, S. Combined analysis of efficacy: The addition of bevacizumab to fluorouracil/leucovorin improves survival in patiens with metastatic colorectal cancer. J. Clin. Oncol. 2005, 23, 3706-3712. [CrossRef] [PubMed]

4. Saltz, L.B.; Clarke, S.; Díaz-Rubio, E.; Scheithauer, W.; Figer, A.; Wong, R.; Koski, S.; Lichinitser, M.; Yang, T.S.; Rivera, F.; et al. Bevacizumab in combination with oxaliplatin-based chemotherapy as first-line therapy in metastatic colorectal cancer: A randomized phase III study. J. Clin. Oncol. 2008, 26, 2013-2019. [CrossRef] [PubMed]

5. Kozloff, M.; Yood, M.U.; Berlin, J.; Flynn, P.J.; Kabbinavar, F.F.; Purdie, D.M.; Ashby, M.A.; Dong, W.; Sugrue, M.M.; Grothey, A.; et al. Clinical outcomes associated with bevacizumab-containing treatment of metastatic colorectal cancer: The BRiTE observational cohort study. Oncologist 2009, 14, 862-870. [CrossRef] [PubMed]

6. Van Cutsem, E.; Rivera, F.; Berry, S.; Kretzschmar, A.; Michael, M.; DiBartolomeo, M.; Mazier, M.A.; Canon, J.L.; Georgoulias, V.; Peeters, M.; et al. Safety and efficacy of first-line bevacizumab with FOLFOX, XELOX, FOLFIRI and fluoropyrimidines in metastatic colorectal cancer: The BEAT study. Ann. Oncol. 2009, 20, 1842-1847. [CrossRef]

7. Tang, J.; Li, Z.; Lu, L.; Cho, C.H. ß-Adrenergic system, a backstage manipulator regulating tumour progression and drug target in cancer therapy. Semin. Cancer Biol. 2013, 23, 533-542. [CrossRef]

8. Lang, K.; Drell, T.L.; Lindecke, A.; Niggemann, B.; Kaltschmidt, C.; Zaenker, K.S.; Entschladen, F. Induction of a metastatogenic tumor cell type by neurotransmitters and its pharmacological inhibition by established drugs. Int. J. Cancer 2004, 112, 231-238. [CrossRef]

9. Masur, K.; Niggemann, B.; Zanker, K.S.; Entschladen, F. Norepinephrine-induced migration of SW 480 colon carcinoma cells is inhibited by beta-blockers. Cancer Res. 2001, 61, 2866-2869.

10. Zhang, D.; Ma, Q.Y.; Hu, H.T.; Zhang, M. $\beta 2$-adrenergic antagonists suppress pancreatic cancer cell invasion by inhibiting CREB, NFkappaB and AP-1. Cancer Biol. Ther. 2010, 10, 19-29. [CrossRef]

11. Guo, K.; Ma, Q.; Wang, L.; Hu, H.; Li, J.; Zhang, D.; Zhang, M. Norepinephrine-induced invasion by pancreatic cancer cells is inhibited by propranolol. Oncol. Rep. 2009, 22, 825-830. [PubMed]

12. Sloan, E.K.; Priceman, S.J.; Cox, B.F.; Yu, S.; Pimentel, M.A.; Tangkanangnukul, V.; Arevalo, J.M.; Morizono, K.; Karanikolas, B.D.; Wu, L.; et al. The sympathetic nervous system induces a metastatic switch in primary breast cancer. Cancer Res. 2010, 70, 7042-7052. [CrossRef] [PubMed] 
13. Sood, A.K.; Armaiz-Pena, G.N.; Halder, J.; Nick, A.M.; Stone, R.L.; Hu, W.; Carroll, A.R.; Spannuth, W.A.; Deavers, M.T.; Allen, J.K.; et al. Adrenergic modulation of focal adhesion kinase protects human ovarian cancer cells from anoikis. J. Clin. Investig. 2010, 120, 1515-1523. [CrossRef] [PubMed]

14. Stiles, J.M.; Amaya, C.; Rains, S.; Diaz, D.; Pham, R.; Battiste, J.; Modiano, J.F.; Kokta, V.; Boucheron, L.E.; Mitchell, D.C.; et al. Targeting of beta adrenergic receptors results in therapeutic efficacy against models of hemangioendothelioma and angiosarcoma. PLoS ONE 2013, 8, e60021. [CrossRef] [PubMed]

15. Eisenhauer, E.A.; Therasse, P.; Bogaerts, J.; Schwartz, L.H.; Sargent, D.; Ford, R.; Dancey, J.; Arbuck, S.; Gwyther, S.; Mooney, M.; et al. New response evaluation criteria in solid tumours: Revised RECIST guideline (version 1.1). Eur. J. Cancer 2009, 45, 228-247. [CrossRef]

16. R: A Language and Environment for Statistical Computing. Available online: https://repo.bppt.go.id/cran/ web/packages/dplR/vignettes/intro-dplR.pdf (accessed on 20 December 2018).

17. A Package for Survival Analysis in S. Available online: https://CRAN.R-project.org/package=survival (accessed on 27 November 2018).

18. Survminer: Drawing survival curves using "ggplot2". Available online: https://rpkgs.datanovia.com/ survminer/index.html (accessed on 5 August 2018).

19. Schuller, H.M. Beta-adrenergic signaling, a novel target for cancer therapy? Oncotarget 2010, 1, 466-469. [CrossRef]

20. Schuller, H.M. Neurotransmitter receptor-mediated signaling pathways as modulators of carcinogenesis. Prog. Exp. Tumor. Res. 2007, 39, 45-63. [PubMed]

21. Wong, H.P.; Ho, J.W.; Koo, M.W.; Yu, L.; Wu, W.K.; Lam, E.K.; Tai, E.K.; Ko, J.K.; Shin, V.Y.; Chu, K.M.; et al. Effects of adrenaline in human colon adenocarcinoma HT-29 cells. Life Sci. 2011, 88, 1108-1112. [CrossRef]

22. Wu, W.K.; Wong, H.P.; Luo, S.W.; Chan, K.; Huang, F.Y.; Hui, M.K.; Lam, E.K.; Shin, V.Y.; Ye, Y.N.; Yang, Y.H.; et al. 4-(Methylnitrosamino)-1-(3-pyridyl)-1-butanone from cigarette smoke stimulates colon cancer growth via beta-adrenoceptors. Cancer Res. 2005, 65, 5272-5277. [CrossRef]

23. Sastry, K.S.; Karpova, Y.; Prokopovich, S.; Smith, A.J.; Essau, B.; Gersappe, A.; Carson, J.P.; Weber, M.J.; Register, T.C.; Chen, Y.Q.; et al. Epinephrine protects cancer cells from apoptosis via activation of cAMP-dependent protein kinase and BAD phosphorylation. J. Biol. Chem. 2007, 282, 14094-14100. [CrossRef]

24. Yang, E.V.; Sood, A.K.; Chen, M.; Li, Y.; Eubank, T.D.; Marsh, C.B.; Jewell, S.; Flavahan, N.A.; Morrison, C.; Yeh, P.E.; et al. Norepinephrine up-regulates the expression of vascular endothelial growth factor, matrix metalloproteinase (MMP)-2, and MMP-9 in nasopharyngeal carcinoma tumor cells. Cancer Res. 2006, 66, 10357-10364. [CrossRef] [PubMed]

25. Drell, T.L.; Joseph, J.; Lang, K.; Niggemann, B.; Zaenker, K.S.; Entschladen, F. Effects of neurotransmitters on the chemokinesis and chemotaxis of MDA-MB-468 human breast carcinoma cells. Breast Cancer Res. Treat. 2003, 80, 63-70. [CrossRef] [PubMed]

26. Nilsson, M.B.; Armaiz-Pena, G.; Takahashi, R.; Lin, Y.G.; Trevino, J.; Li, Y.; Jennings, N.; Arevalo, J.; Lutgendorf, S.K.; Gallick, G.E.; et al. Stress hormonesregulate interleukin-6 expression by human ovarian carcinoma cells through a Src-dependent mechanism. J. Biol. Chem. 2007, 282, 29919-29926. [CrossRef] [PubMed]

27. Cole, S.W.; Arevalo, J.M.; Takahashi, R.; Sloan, E.K.; Lutgendorf, S.K.; Sood, A.K.; Sheridan, J.F.; Seeman, T.E. Computational identification of gene-social environment interaction at the human IL6 locus. Proc. Natl. Acad. Sci. USA 2010, 107, 5681-5686. [CrossRef] [PubMed]

28. Shahzad, M.M.; Arevalo, J.M.; Armaiz-Pena, G.N.; Lu, C.; Stone, R.L.; Moreno-Smith, M.; Nishimura, M.; Lee, J.W.; Jennings, N.B.; Bottsford-Miller, J.; et al. Stress effects on FosB and interleukin-8 (IL8) -driven ovarian cancer growth and metastasis. J. Biol. Chem. 2010, 285, 35462-35470. [CrossRef] [PubMed]

29. Thaker, P.H.; Han, L.Y.; Kamat, A.A.; Arevalo, J.M.; Takahashi, R.; Lu, C.; Jennings, N.B.; Armaiz-Pena, G.; Bankson, J.A.; Ravoori, M.; et al. Chronic stress promotes tumor growth and angiogenesis in a mouse model of ovarian carcinoma. Nat. Med. 2006, 12, 939-944. [CrossRef]

30. Chakroborty, D.; Sarkar, C.; Basu, B.; Dasgupta, P.S.; Basu, S. Catecholamines regulate tumor angiogenesis. Cancer Res. 2009, 69, 3727-3730. [CrossRef]

31. Grytli, H.H.; Fagerland, M.W.; Fossa, S.D.; Tasken, K.A. Association between use of beta-blockers and prostate cancer-specific survival: A cohort study of 3561 prostate cancer patients with high-risk or metastatic disease. Eur. Urol. 2014, 65, 635-641. [CrossRef] 
32. Grytli, H.H.; Fagerland, M.W.; Fossa, S.D.; Tasken, K.A.; Haheim, L.L. Use of beta-blockers is associated with prostate cancer-specific survival in prostate cancer patients on androgen deprivation therapy. Prostate 2013, 73, 250-260. [CrossRef]

33. Barron, T.I.; Connolly, R.M.; Sharp, L.; Bennett, K.; Visvanathan, K. Beta blockers and breast cancer mortality: A population-based study. J. Clin. Oncol. 2011, 29, 2635-2644. [CrossRef]

34. Melhem-Bertrandt, A.; Chavez-Macgregor, M.; Lei, X.; Brown, E.N.; Lee, R.T.; Meric-Bernstam, F.; Sood, A.K.; Conzen, S.D.; Hortobagyi, G.N.; Gonzalez-Angulo, A.M. Beta-blocker use is associated with improved relapse-free survival in patients with triple-negative breast cancer. J. Clin. Oncol. 2011, 29, 2645-2652. [CrossRef] [PubMed]

35. Botteri, E.; Munzone, E.; Rotmensz, N.; Cipolla, C.; De Giorgi, V.; Santillo, B.; Zanelotti, A.; Adamoli, L.; Colleoni, M.; Viale, G.; et al. Therapeutic effect of $\beta$-blockers in triple-negative breast cancer postmenopausal women. Breast Cancer Res. Treat. 2013, 140, 567-575. [CrossRef] [PubMed]

36. Spera, G.; Fresco, R.; Fung, H.; Dyck, J.R.B.; Pituskin, E.; Paterson, I.; Mackey, J.R. Beta blockers and improved progression free survival in patients with advanced HER2 negative breast cancer: A retrospective analysis of the ROSE/TRIO-012 study. Ann. Oncol. 2017, 28, 1836-1841. [CrossRef] [PubMed]

37. De Giorgi, V.; Gandini, S.; Grazzini, M.; Benemei, S.; Marchionni, N.; Geppetti, P. Effect of $\beta$-blockers and other antihypertensive drugs on the risk of melanoma recurrence and death. Mayo Clin. Proc. 2013, 88, 1196-1203. [CrossRef] [PubMed]

38. Lemeshow, S.; Sorensen, H.T.; Phillips, G.; Yang, E.V.; Antonsen, S.; Riis, A.H.; Lesinski, G.B.; Jackson, R.; Glaser, R. $\beta$-blockers and survival among Danish patients with malignant melanoma: A population-based cohort study. Cancer Epidemiol. Biomark. Prev. 2011, 20, 2273-2279. [CrossRef]

39. Beg, M.S.; Gupta, A.; Sher, D.; Ali, S.; Khan, S.; Gao, A.; Stewart, T.; Ahn, C.; Berry, J.; Mortensen, E.M.; et al. Impact of concurrent medication use on pancreatic cancer survival-SEER-medicare analysis. Am. J. Clin. Oncol. 2018, 41, 766-771. [CrossRef]

40. Udumyan, R.; Montgomery, S.; Fang, F.; Almroth, H.; Valdimarsdottir, U.; Ekbom, A.; Smedby, K.; Fall, K. Beta-blocker drug use and survival among patients with pancreatic adenocarcinoma. Cancer Res. 2017, 77 , 3700-3707. [CrossRef]

41. Ganz, P.A.; Habel, L.A.; Weltzien, E.K.; Caan, B.J.; Cole, S.W. Examining the influence of beta blockers and ACE inhibitors on the risk for breast cancer recurrence: Results from the LACE cohort. Breast Cancer Res. Treat. 2011, 129, 549-556. [CrossRef]

42. Jansen, L.; Hoffmeister, M.; Arndt, V.; Chang-Claude, J.; Brenner, H. Stage-specific associations between beta blocker use and prognosis after colorectal cancer. Cancer 2014, 120, 1178-1186. [CrossRef]

43. Giampieri, R.; Scartozzi, M.; Del Prete, M.; Faloppi, L.; Bianconi, M.; Ridolfi, F.; Cascinu, S. Prognostic value for incidental antihypertensive therapy with beta-blockers in metastatic colorectal cancer. Medicine 2015, 94, e719. [CrossRef]

44. Hwa, Y.L.; Shi, Q.; Kumar, S.K.; Lacy, M.Q.; Gertz, M.A.; Kapoor, P.; Buadi, F.K.; Leung, N.; Dingli, D.; Go, R.S.; et al. Beta-blockers improve survival outcomes in patients with multiple myeloma: A retrospective evaluation. Am. J. Hematol. 2017, 92, 50-55. [CrossRef]

45. Diaz, E.S.; Karlan, B.Y.; Li, A.J. Impact of beta blockers on epithelial ovarian cancer survival. Gynecol. Oncol. 2012, 127, 375-378. [CrossRef] [PubMed]

46. Al-Niaimi, A.; Dickson, E.L.; Albertin, C.; Karnowski, J.; Niemi, C.; Spencer, R.; Shahzad, M.M.; Uppal, S.; Saha, S.; Rice, L.; et al. The impact of perioperative beta blocker use on patient outcomes after primary cytoreductive surgery in high-grade epithelial ovarian carcinoma. Gynecol. Oncol. 2016, 143, 521-525. [CrossRef]

47. Watkins, J.L.; Thaker, P.H.; Nick, A.M.; Ramondetta, L.M.; Kumar, S.; Urbauer, D.L.; Matsuo, K.; Squires, K.C.; Coleman, R.L.; Lutgendorf, S.K.; et al. Clinical impact of selective and nonselective beta-blockers on survival in patients with ovarian cancer. Cancer 2015, 121, 3444-3451. [CrossRef] [PubMed]

48. Kim, S.A.; Moon, H.; Roh, J.L.; Kim, S.B.; Choi, S.H.; Nam, S.Y.; Kim, S.Y. Postdiagnostic use of beta-blockers and other antihypertensive drugs and the risk of recurrence and mortality in head and neck cancer patients: An observational study of 10, 414 person-years of follow-up. Clin. Transl. Oncol. 2017, 19, 826-833. [CrossRef] [PubMed] 
49. Wang, H.M.; Liao, Z.X.; Komaki, R.; Welsh, J.W.; O’Reilly, M.S.; Chang, J.Y.; Zhuang, Y.; Levy, L.B.; Lu, C.; Gomez, D.R. Improved survival outcomes with the incidental use of beta-blockers among patients with non-small-cell lung cancer treated with definitive radiation therapy. Ann. Oncol. 2013, 24, 1312-1319. [CrossRef] [PubMed]

50. Musselman, R.P.; Li, W.; Gomes, T.; Mamdani, M.; Haggar, F.; Moloo, H.; Boushey, R.P.; Al-Omran, M.; Al-Obeed, O.; Van Walraven, C.; et al. Association between beta blocker usage and cancer survival in a large, matched population study among hypertensive patients. J. Surg. Res. 2014, 186, 639-640. [CrossRef]

51. Holmes, S.; Griffith, E.J.; Musto, G.; Minuk, G.Y. Antihypertensive medications and survival in patients with cancer: A population-based retrospective cohort study. Cancer Epidemiol. 2013, 37, 881-885. [CrossRef]

52. Assayag, J.; Pollak, M.N.; Azoulay, L. Post-diagnostic use of beta-blockers and the risk of death inpatients with prostate cancer. Eur. J. Cancer 2014, 50, 2838-2845. [CrossRef]

53. Sakellakis, M.; Kostaki, A.; Starakis, I.; Koutras, A. Beta-blocker use and risk of recurrence in patients with early breast cancer. Chemotherapy 2014, 60, 288-289. [CrossRef]

54. Livingstone, E.; Hollestein, L.M.; van Herk-Sukel, M.P.; Van de Poll-Franse, L.; Nijsten, T.; Schadendorf, D.; De Vries, E. $\beta$-Blocker use and all-cause mortality of melanoma patients: Results from a population-based Dutch cohort study. Eur. J. Cancer 2013, 49, 3863-3871. [CrossRef] [PubMed]

55. Cata, J.P.; Villarreal, J.; Keerty, D.; Thakar, D.R.; Liu, D.D.; Sood, A.K.; Gottumukkala, V. Perioperative beta-blocker use and survival in lung cancer patients. J. Clin. Anesth. 2014, 26, 106-117. [CrossRef] [PubMed]

56. Heitz, F.; Hengsbach, A.; Harter, P.; Traut, A.; Ataseven, B.; Schneider, S.; Prader, S.; Kurzeder, C.; Sporkmann, M.; Du Bois, A. Intake of selective beta blockers has no impact on survival in patients with epithelial ovarian cancer. Gynecol. Oncol. 2017, 144, 181-186. [CrossRef] [PubMed]

57. Johannesdottir, S.A.; Schmidt, M.; Phillips, G.; Glaser, R.; Yang, E.V.; Blumenfeld, M.; Lemeshow, S. Use of B-blockers and mortality following ovarian cancer diagnosis: A population-based cohort study. BMC Cancer 2013, 13, e85. [CrossRef] [PubMed]

58. Heitz, F.; du Bois, A.; Harter, P.; Lubbe, D.; Kurzeder, C.; Vergote, I.; Plante, M.; Pfisterer, J.; AGO Study Group; NCIC-CTG Study Group; et al. Impact of beta blocker medication in patients with platinum sensitive recurrent ovarian cancer-a combined analysis of 2 prospective multicenter trials by the AGO Study Group, NCIC-CTG and EORTC-GCG. Gynecol. Oncol. 2013, 129, 463-466. [CrossRef] [PubMed]

59. Jansen, L.; Weberpals, J.; Kuiper, J.G.; Vissers, P.A.J.; Wolkewitz, M.; Hoffmeister, M.; Brenner, H. Pre- and post-diagnostic beta-blocker use and prognosis after colorectal cancer: Results from a population-based study. Int. J. Cancer 2017, 141, 62-71. [CrossRef]

60. Hicks, B.M.; Murray, L.J.; Powe, D.G.; Hughes, C.M.; Cardwell, C.R. B-Blocker usage and colorectal cancer mortality: A nested case-control study in the UK Clinical Practice Research Datalink cohort. Ann. Oncol. 2013, 24, 3100-3106. [CrossRef]

61. Choi, C.H.; Song, T.J.; Kim, T.H.; Choi, J.K.; Park, J.Y.; Yoon, A.; Lee, Y.Y.; Kim, T.J.; Bae, D.S.; Lee, J.W.; et al. Meta-analysis of the effects of beta blocker on survival time in cancer patients. J. Cancer Res. Clin. Oncol. 2014, 140, 1179-1188. [CrossRef]

62. Zhong, S.; Yu, D.; Zhang, X.; Chen, X.; Yang, S.; Tang, J.; Zhao, J.; Wang, S. $\beta$-blocker use and mortality in cancer patients: Systematic review and meta-analysis of observational studies. Eur. J. Cancer Prev. 2016, 25, 440-448. [CrossRef]

63. Na, Z.; Qiao, X.; Hao, X.; Fan, L.; Xiao, Y.; Shao, Y.; Sun, M.; Feng, Z.; Guo, W.; Li, J.; et al. The effects of beta-blocker use on cancer prognosis: A meta-analysis based on 319,006 patients. OncoTargets Ther. 2018, 11, 4913-4944. [CrossRef]

64. Shyu, K.G.; Liou, J.Y.; Wang, B.W.; Fang, W.J.; Chang, H. Carvedilol prevents cardiac hypertrophy and overexpression of hypoxia-inducible factor-1a and vascular endothelial growth factor in pressure-overloaded rat heart. J. Biomed. Sci. 2005, 12, 409-420. [CrossRef]

65. Shyu, K.G.; Lu, M.J.; Chang, H.; Sun, H.Y.; Wang, B.W.; Kuan, P. Carvedilol modulates the expression of hypoxia-inducible factor-alpha and vascular endothelial growth factor in a rat model of volume-overload heart failure. J. Card. Fail. 2005, 11, 152-159. [CrossRef]

66. Schiestl, C.; Neuhaus, K.; Zoller, S.; Subotic, U.; Forster-Kuebler, I.; Michels, R.; Balmer, C.; Weibel, L. Efficacy and safety of propranolol as first-line treatment for infantile hemangiomas. Eur. J. Pediatr. 2011, 170, 493-501. [CrossRef] 
67. Manunza, F.; Syed, S.; Laguna, B.; Linward, J.; Kennedy, H.; Gholam, K.; Glover, M.; Giardini, A.; Harper, J.I. Propranolol for complicated infantile haemangiomas: A case series of 30 infants. Br. J. Dermatol. 2010, 162, 466-468. [CrossRef]

68. Cai, J.; Ma, H.; Huang, F.; Zhu, D.; Bi, J.; Ke, Y.; Zhang, T. Correlation of bevacizumab-induced hypertension and outcomes of metastatic colorectal cancer patients treated with bevacizumab: A systematic review and meta-analysis. World J. Surg. Oncol. 2013, 111, e306. [CrossRef] 